\title{
ZPRÁVA O FILOSOFICKÝCH UDÁLOSTECH POŘÁDANÝCH SPOLEČNOSTÍ PRO FILOSOFICKOU ANTROPOLOGII
}

\section{Semináře Společnosti pro filosofickou antropologii}

V roce 2017 vznikla Společnost pro filosofickou antropologii (SFA) jakožto institučně nezávislá, otevřená platforma pro diskusi filosofických tematizací člověka. Počínaje rokem 2018 SFA organizuje pravidelné semináře, kde hosté z různých institucí prezentují své aktuální filosofické výzkumy. Semináře se doposud zúčastnili Jakub Marek s nietzschovskou přednáškou ,Stř̌ezte se filosofů, již přinášejí dary“, Jakub Sirovátka s přednáškou „Náboženství jako ,nutný doplněk“ etiky Immanuela Kanta“, Josef Kružík promluvil na téma „Raptus v Paradiso XXXIII Dantovy Božské komedie“, Václav Zajíc vystoupil s přednáškou „Čím je ve filosofii názor a proč by nás to mělo zajímat“, Zdeněk Kratochvíl potěšil posluchače prezentací „Archaické a klasické: obecná dichotomie v myšlení a umění na př́íkladech z raných a pozdních presokratiků i na sochařství a vázovém malîrstvii“", následně vystoupil Peter Trawny s dvěma přednáškami, o nichž pojednáme níže. Do začátku léta pak v semináři promluvili ještě Jiří Hoblík (,Starozákonní antropologie“), Jan Frei („Existenciální poznání podle Heinricha Bartha“) a Martin Vrabec (,Schellingovo tzv. antropologické schéma“).

\section{Přednášky Petera Trawnyho}

Ve dnech 24. a 25. dubna 2018 zavítal do Prahy Peter Trawny, jenž je vydavatelem př́slušných svazků Heideggerových sebraných spisů. Profesor Trawny se nabídl, že u př́ležitosti dvoustého výročí narození Karla Marxe promluví kriticky na téma Marxova pojetí revoluce, jemuž je věnována jeho nejnovější kniha Der frühe Marx und die Revolution (Raný Marx a revoluce, 2018), zejména však dostal př́ležitost vyslovit se ke své knize Heidegger und der Mythos der jüdischen Weltverschwörung (Heidegger a mýtus židovského světového spiknutí, 2014). V přednášce „Nový způsob četby Martina Heideggera“ tak představil svou metodu čtení a interpretace spisů tohoto myslitele, která klade velký důraz na materiální stránku Heideggerova myšlení v podobě jeho manuskriptů a celé autorské a ediční strategie, kterou s nimi Heidegger spojoval. ${ }^{1}$

\section{Workshop „Husserlovo dědictví“ u příležitosti osmdesátého výročí} filosofova úmrtí

V roce 2018 si připomínáme osmdesát let od skonu Edmunda Husserla, zakladatele fenomenologické metody filosofického výzkumu. U této př́iležitosti byl uspořádán workshop nazvaný „Husserlovo dědictvi““ (jde o explicitní poukaz na nejnovější knihu Dana Zahaviho Husserl's Legacy, 2017), který měl ná-

1 Audiovizuální záznamy přednášek Petera Trawnyho jsou k nalezení na kanálu Společnosti pro filosofickou antropologii na serveru Youtube. 
sledující program: Hynek Janoušek, „Zrod Husserlova pojmu intencionality“; Václav Zajíc, „Husserl mezi počitkem a naladěním“; Ivan Blecha, „Goodmanova teorie zobrazení a fenomenologie“; Josef Matoušek, „Lévinas, Sartre a limity intencionality. První kritická rozvinutí Husserlovy fenomenologie ve Francii“; David Rybák, „Žitý svět a universum“; Aleš Novák, „Vědecká filosofie, světový názor a ,Tiefsinn': tři podoby filosofie v Husserlově článku Filosofie jako př́sná věda".

Společnost nyní plánuje další semináře a workshopy, jež budou věnovány rozličným filosofickým problémům.

Aleš Novák 